\title{
Influence of measurement areas selection on roughness parameters in burnished surfaces measurements
}

\author{
Wpływ doboru obszarów pomiarowych na parametry chropowatości \\ w pomiarach powierzchni nagniatanych
}

ANETA ŁĘTOCHA
TATIANA MILLER
JANUSZ KALISZ *

Paper presents part of the research performed in order to optimization the methodology of surface texture evaluation of samples produced by medium milling and subsequent finish by roller burnishing. Tests related with influence of measurement areas selection on roughness parameters were performed. Research allows on evaluation of homogeneity of burnished samples surfaces.

KEYWORDS: surface roughness, burnishing, optimization, measurement methodology

Artykuł przedstawia część badań mających na celu zoptymalizowanie metodyki oceny struktury geometrycznej powierzchni po obróbce sekwencyjnej frezowaniem i nagniataniem. Przeprowadzono badania związane $z$ wpływem doboru obszaru pomiarowego na parametry chropowatości. Badania pozwoliły na ocenę jednorodności powierzchni próbek nagniatanych.

SŁOWA KLUCZOWE: chropowatość powierzchni, nagniatanie, optymalizacja, metodyka pomiaru

Way of machine elements and another products wear is the most often depended from properties of them top layer, especially of surface texture, material hardness and residual stresses status that left after machining. Appropriate properties of top layer can be formed inter alia during finishing burnishing, based on item local cold plastic deformation as a result of force and kinetic cooperation of smooth tool and machined surface $[1 \div 3]$. For surface texture research can be used many different measurement methods. Roughness profile measurements using contact profiling method are very accurate. The method is based on movement of measurement probe, equipped in inductive transmitter, along measured surface with selected speed. Cone-shaped, small diamond tip of the probe, with radius about few micrometres $(<10 \mu \mathrm{m})$, is vertically leaned out depending on the surface texture. Areal measurement in contact method is based on converting profiles on part of surface $[4 \div 6]$. Although contact method is one of the best way for surface texture measurement, improper selection of measurement area on the sample and number of measurements can easily lead to results distortion. This paper presents results of tests performed in order to find how measurement areas selection influences on roughness parameters.

\section{Samples, measurement and analysis}

During research sample of EM AW-AICu4MgSi(A) aluminum alloy in hardened state T451 was used. Sample was

\footnotetext{
* Mgr inż. Aneta Łętocha (aneta.letocha@ios.krakow.pl), mgr inż. Tatiana Miller (tatiana.miller@ios.krakow.pl), mgr inż. Janusz Kalisz (janusz.kalisz@ios.krakow.pl) - Instytut Zaawansowanych Technologii Wytwarzania
}

milled using a monolithic ball-end cutter (VHM) of a $8 \mathrm{~mm}$ diameter with the cutting speed of $v_{c}=350 \mathrm{~m} / \mathrm{min}$, the feed per tooth of $f_{z}=0.04 \mathrm{~mm}$, the pitch (stepover) of $f_{w f}=0.53 \mathrm{~mm}$ and the axial depth of cut (the back engagement) $a_{p}=0.5 \mathrm{~mm}$. Milling operation (Fig. 1) was performed with the constant stepover and the tilt angle $(\psi)$ of $7.5^{\circ}$ in the direction perpendicular to the $Y$ axis. Both milling and burnishing operations were carried out, each in one pass on a 5-axis machining centre model DMC $75 \mathrm{~V}$ Linear. Burnishing was performed using a springloaded burnishing tool (produced by The Institute of Advanced Manufacturing Technology) equipped with a $\mathrm{Si}_{3} \mathrm{~N}_{4}$ ceramic polished ball of a $8 \mathrm{~mm}$ diameter. The values of the elastic load were equal to $F_{n}=75 \mathrm{~N}$, whereas the feed rates in the direction perpendicular to milling lays were equal to $f_{w n}=0.02 \mathrm{~mm}$ and $0.04 \mathrm{~mm}$. During burnishing the ball was lubricated by machine oil.

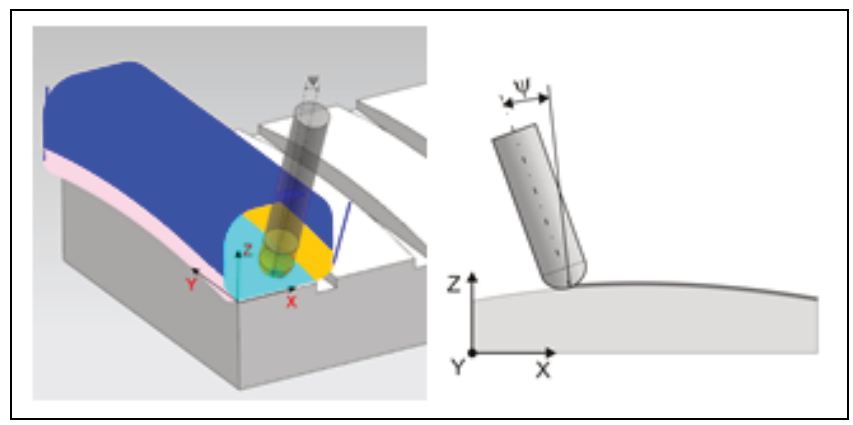

Fig. 1. Scheme of samples ball-end milling in the direction perpendicular to $Y$ axis (left) and the tilt angle $(\psi)$ (right)

Surface texture measurements were performed using contact profilometer TOPO 01 constructed by the Institute of Advanced Manufacturing Technology (Fig. 2). Instrument was equipped in probe with $2 \mu \mathrm{m}$ radius and $60^{\circ}$ angle cone tip.

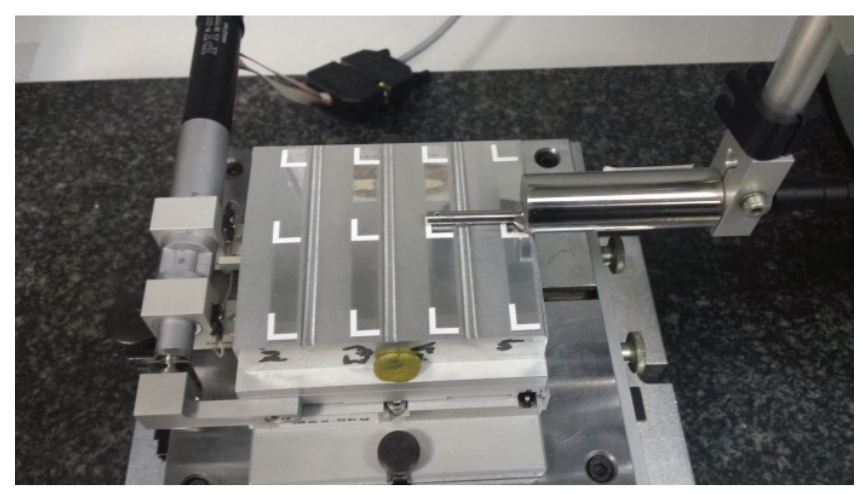

Fig. 2. Contact method measurement of burnished surfaces using TOPO 01 instrument 
Measurement speed was $0.5 \mathrm{~mm} / \mathrm{s}$, sampling rate in $X$ axis (measurement direction axis) $d X=0.5 \mu \mathrm{m}$, and in axis perpendicular to measurement direction $d Y=5 \mu \mathrm{m}$. There were three series of measurements. In first series six measurements in completely different places on the surface were performed, each with designated $1.25 \times 2 \mathrm{~mm}$ area. Second series included eleven measurements performed with small shift. Each measurement was shifted relative to the previous about $0.2 \mathrm{~mm}$ both in $X$ and $Y$ axis. Measurement area was equal $1.25 \times 2 \mathrm{~mm}$. Third series of measurements was performed in the same place and includes 11 reps on $1.25 \times 1 \mathrm{~mm}$ measurement area. In all analysis Gaussian filter (cut-off $=0.25 \mathrm{~mm}$ ) were used. Roughness profile parameters were calculated: $R a, R q, R p, R v, R z, R c, R t$.

\section{Results}

Tab. I presents calculated results of standard deviations of mean value. Tab. II presents in percentage proportion of results range to mean value of those results in calculation of roughness profile parameters. Designations used in Tab. I and in Tab. II:

- DIFF-every measurement performed on completely different area on the sample,

- SMALL - small shifts of measurement area (in neighbourhood of first measurement),

- SAME - measurements performed in the same place.

TABLE I. Standard deviations of mean value of roughness profile parameters

\begin{tabular}{|c|c|c|c|}
\hline Parameter & DIFF, $\mu \mathrm{m}$ & SMALL, $\mu \mathrm{m}$ & SAME, $\mu \mathrm{m}$ \\
\hline$R a$ & 0.0010 & 0.0002 & 0.0001 \\
\hline$R q$ & 0.0015 & 0.0002 & 0.0002 \\
\hline$R p$ & 0.0021 & 0.0005 & 0.0003 \\
\hline$R v$ & 0.0060 & 0.0003 & 0.0003 \\
\hline$R z$ & 0.0078 & 0.0007 & 0.0004 \\
\hline$R c$ & 0.0033 & 0.0004 & 0.0003 \\
\hline$R t$ & 0.0174 & 0.0008 & 0.0006 \\
\hline
\end{tabular}

TABLE II. Proportion of results range to mean value of roughness profile parameters

\begin{tabular}{|c|c|c|c|}
\hline Parameter & DIFF, \% & SMALL, \% & SAME, \% \\
\hline$R a$ & 32.4 & 11.7 & 6.2 \\
\hline$R q$ & 38.0 & 9.3 & 9.6 \\
\hline$R p$ & 24.2 & 8.4 & 6.5 \\
\hline$R v$ & 50.1 & 5.9 & 5.6 \\
\hline$R z$ & 38.9 & 7.1 & 5.0 \\
\hline$R c$ & 40.6 & 9.5 & 9.8 \\
\hline$R t$ & 52.8 & 6.2 & 4.0 \\
\hline \multicolumn{4}{|l}{} \\
\hline
\end{tabular}

Fig. 3 presents graph illustrating results of first measurement series - deviations from calculated mean values of roughness profile parameters, in percentage. Fig. 4 presents graph illustrating results of second measurement series - deviations from calculated mean values of roughness profile parameters, in percentage. Fig. 5 presents graph illustrating results of third measurement series - deviations from calculated mean values of roughness profile parameters, in percentage.

\section{Summary}

One can see that results obtained in measurements performed on completely different areas are significantly higher - up to twenty times for standard deviations of mean value and up to eight times for proportion of results range to mean value - than measurements performed with small shifts of measurement area. Results obtained in measurements in the same place are similar to those from second series. Small changes of location of measurement start point causes usually insignificant increase of results range. To fully evaluate burnished surfaces, it is necessary to perform at very least three measurements in completely different areas on the sample, because they are not completely homogeneous.

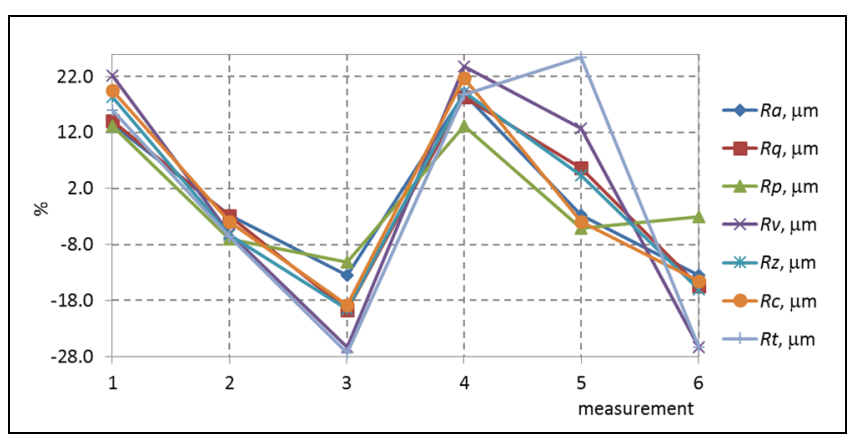

Fig. 3. Results deviation from mean values of roughness profile parameters for measurments performed in different areas

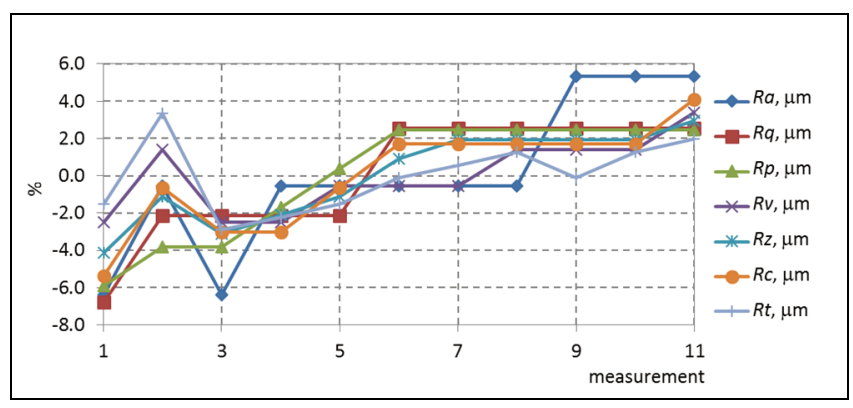

Fig. 4. Results deviation from mean values of roughness profile parameters for measurements performed in neighbourhood of first measurement

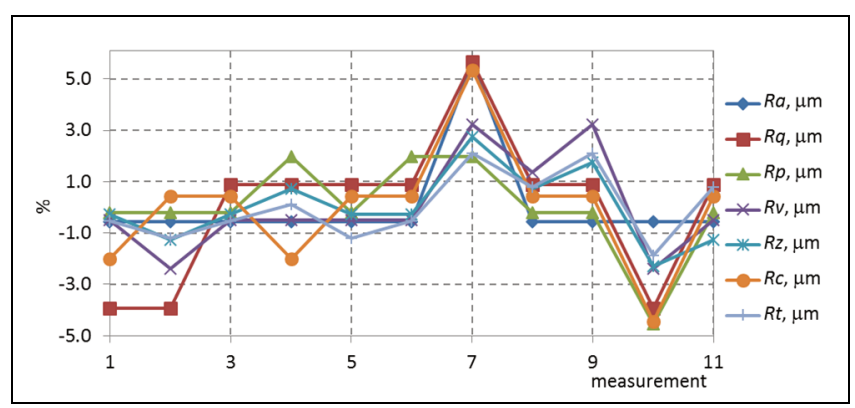

Fig. 5. Results deviation from mean values of roughness profile parameters for measurements performed in the same place

Research works performed Statutory Activities of the Institute of Advanced Manufacturing Technology and the evaluate the reliability of measurement results was carried out as a part of the project no. PBS2/A6/20/2013/NCBiR/24/10/2013 "Research and evaluation of reliability of modern methods of surface topography measurements in micro and nano scale"

\section{LITERATURE}

1. Przybylski W. „Technologia obróbki nagniataniem”. Warszawa: Wydawnictwo Naukowo-Techniczne, 1987.

2. Grochała D., Chmielewski K., Olszak W. „Badania wpływu technologicznych parametrów frezowania i nagniatania na topografię powierzchni”. XII Konferencja Naukowa Technologia obróbki przez nagniatanie. Mechanik. R. 87, nr 11CD (2014): s. $937 / 90 \div 99$.

3. Kalisz J., Janczewski Ł., Czechowski K., Czerwiński A., Polowski W., Łętocha A. „Rozwój technologii nagniatania tocznego powierzchni frezowanych". Mechanik. R. 87, nr 3 (2014): s. $186 \div 189$.

4. Jakubiec W., Zator S., Majda P. „Metrologia”, Warszawa: Polskie Wydawnictwo Ekonomiczne, 2014.

5. Wieczorowski M. „Metrologia nierówności powierzchni. Metody i systemy". Szczecin: ZAPOL, 2013.

6. Wieczorowski M. „Wykorzystanie analizy topograficznej w pomiarach nierówności powierzchni”. Poznań: Wydawnictwo Politechniki Poznańskiej, 2009. 